FACTA UNIVERSITATIS

Series: Visual Arts and Music Vol. 6, No 2, 2020, pp. 105 - 115

https://doi.org/10.22190/FUVAM2002105Z

Original scientific paper

\title{
TREATMENT OF RECAPITULATION OF THE FIRST MOVEMENTS IN THE SONATA FORM OF BEETHOVEN'S STRING QUARTETS OP. 18
}

\author{
UDC 781.5.082.2:787.1/.4 L. van Beethoven
}

Danijela Zdravić Mihailović

University of Niš, Faculty of Arts in Niš, Serbia

\begin{abstract}
The paper focuses on the function of recapitulation in the sonata form relying on the example of the first movements of Beethoven's string quartets Op. 18 No. $1-6$. With regard to the fact that recapitulation is commonly described as a restatement of the exposition with tonal alterations of the second theme and the closing section, analytical deliberations most often do not go beyond recording such alterations. However, some analysis point to the new role of the recapitulation exactly on account of the essence of the undertaken alterations, i.e. on account of the idea that the composer wants to accomplish at the level of sonata form through recapitulation. The research is conceived as a continuation of the previous studies (Zdravić Mihailović 2006, 2007a, 2007b, 2015a, 2015b). These studies focused on the genre of string quartet of Franz Joseph Haydn and Wolfgang Amadeus Mozart, where recapitulation was proven to be a remarkable phenomenon as its role was not merely to restate the exposition's content with the usual tonal alterations. On the contrary, it can be a place of a new treatment of the sections of the exposition, and gives it some completely specific features.
\end{abstract}

Key words: recapitulation, sonata form, Beethoven, string quartet.

\section{INTRODUCTION}

The analysis of the recapitulation within the sonata form is mainly focused on the way that alterations in it relate to the exposition. This means that the analytical course is most often oriented towards designating the thematic, tonal and structural plans of the exposition, and then towards a comparative analysis of the exposition's sections in the recapitulation. Therefore recapitulation, as a section based on the altered repetition of the exposition, is mainly described in the context of such adaptations with regard to the exposition. When

Received October 2020 / Accepted November 2020

Corresponding author: Danijela Zdravić Mihailović

University of Niš, Faculty of Arts in Niš

E-mail: dzdravicmihailovic@yahoo.com 
setting out typical forms - bi-thematic content of the exposition that includes unfolding of the second theme and the closing section in the dominant key (or parallel key if the movement is in a minor key) and tonal reconciliation of the themes in the recapitulation, i.e. unfolding of the second theme in the home key - musical theoreticians most often refer to the compositions of the Viennese Classicists. Such an approach ensures certain standardization of the undertaken alterations, but even in such samples it is possible to find some distinctive compositional and technical solutions.

The common alterations which are usually mentioned are tonal reconciliation of themes and (optionally) modification of the bridge (transition) ${ }^{1}$ aimed at preparing the key for the onset of the second theme, as well as additional alterations of the structure, texture, dynamics, instrumentation, which do not significantly disturb the content of the exposition. As far as the bridge is concerned, it can be said that it necessarily carries within itself the idea of change, because it represents the point of transition between the themes, as much in the exposition as in the recapitulation, "Since recapitulation stays in the tonic where the exposition went into another key, the point of transition between those two keys always has to be rewritten" (Cook 1994, 274).

Some more significant deviations in the recapitulation are addressed to as exceptions (Mihajlović 1989, 57; Skovran and Peričić 1982, 161) and they include deceptive (false) recapitulation, subdominant recapitulation, beginning of the second theme in a new key followed by a return to the home key, reversed (inverted) recapitulation, leaving out the first theme in the recapitulation and a contrapuntal blending of both themes in the recapitulation. Taking into account the fact that some particularly significant alterations have been given particular consideration, analytical attention is focused around two cardinal issues - is recapitulation common with the alterations inherent to it, or it contains significant deviations from the exposition, i.e. involves some exception? However, analytical practice should not uphold only this approach, because it does not provide enough particularities about the idea behind the undertaken alterations. In the earlier researches (Zdravić Mihailović 2015b, 423) it was pointed out that this approach is also debatable because the process of formation of the classical sonata form necessarily entailed an alteration of its own constituents, meaning that the issue of "regularity" and "irregularity" remains open, i.e. preconditioned by the context of time and style. A similar attitude is upheld by Ivana Stamatovic $(2004,103)$, who makes the point that standardization of the sonata form, for instance, in the music theory of the 19th century was carried out in such a way as to reflect the pattern of understanding music typical for that particular period. Nevertheless, the standard established in such a way which relies on its own aesthetics and (ideological) background, cannot be automatically transferred backwards to a period governed by some other aesthetics (and some other ideology).

Charles Rosen also points to the limitations involved in viewing recapitulation strictly in the light of the rule - exception principle, even within a single style (Rosen 1979, 92). According to him, taking the term recapitulation (reprise) to mean a simple repetition of the exposition with the second theme on the tonic, the entire idea must be discarded as non-classical, as such a type of recapitulation was more of an exception than a rule in Haydn's, Mozart's and Beethoven's mature works. Rosen's attitude shows that the very idea of the rule - exception principle is not fully substantiated, as it is not supported by the examples from music literature. Hence, 'regular' recapitulations should prevail in order to be able to talk about a limited number of exceptions. Therefore, it might be that

\footnotetext{
${ }^{11}$ In this paper, the terms bridge and transition are interchangeable.
} 
"a good direction for the layout of the sonata form in textbook literature should rest on the fact that the theory of form in music cannot be isolated from historical considerations, just as the analysis of structure should not be separated from the stylistic, historical and sociological contexts. This further indicates a need to create a relationship towards the sonata form in the plural; we cannot talk about the sonata form (as a uniform model, a single way of conceptualizing), but rather about sonata forms" (Zdravić Mihailović 2016, 35). ${ }^{2}$

Notable alterations in recapitulation, which serve as a distinctive superstructure of the rule-exception principle, are viewed from the point of the degree of remoteness of the alterations in recapitulation against the exposition (see: Zdravić Mihailović 2015a). Besides the regular recapitulation, the author also singles out abbreviated, condensed, and augmented recapitulation, recapitulation with a non-standard order of sections presentation, and tonal peculiarities in the recapitulation, thus pointing out different deviations from the exposition, avoiding a division to regular and irregular. Hence, the author concludes that in order to understand recapitulation it is legitimate to view it as a phenomenon that manifests (to a smaller or greater extent) similarities with the exposition, but also exhibits certain individual features presented in various ways (Ibid., 21).

When contemplating recapitulation, besides the parallel with exposition, it should be taken into account that it is, to a certain degree, affected by the very concept of development. According to Leo Mazel, any significant musical piece that exploits the dynamic potentials of the sonata form faces the "problem of the recapitulation": on the one hand, the dynamic, unstable development itself persuasively calls for a resolution and "rounding" of the form, where a stable recapitulation is the best way to do it. On the other hand, as it has already been mentioned, an undeviating and well-rounded recapitulation is highly improbable in such works. Recapitulation is like an additional step of development, because in many examples it would not be able to bear the burden of development if it stayed at the level of a dynamic exposition (Мазель 1979, 408). Hence, it can be asserted that recapitulation is equally affected by the concept of the exposition, as well as by development because it (recapitulation) can be a remote resolution, as well as "an extended arm" of development.

\section{RECAPITULATION IN BEETHOVEN'S STRING QUARTETS OP. 18 No. 1-6}

A study based on the analysis of the first movements of Beethoven's string quartets Op. 18 No. 1-6 is a continuation of the previous studies (Zdravić Mihailović 2006, 2007b, 2015a, $2015 \mathrm{~b}$ ), and aims at re-examining the ways of altering recapitulation according to the previously established typology, as well as to draw attention to the notable alterations referred to as dynamisation of recapitulation. This term is used for notable alterations that imply "building up tension, intensifying of the activities of musical components" (Zatkalik, Medić, Vlajić 2003), and it is also mentioned in recapitulation as regarding a two-part form, "however, melodically varied recapitulations can be found too, as well as some far reaching adaptations of recapitulation in thematic and harmonic terms, with the aim to dynamise recapitulation" (Skovran i Peričić 1982, 91). So, the analytical considerations will not be solely aimed at specifying the deviations of the content of recapitulation against the exposition, but will also provide explanations of the reasons why recapitulation manifests itself in a certain way in the context of the entire sonata form.

${ }^{2}$ Here we bring to your attention Charles Rosen's study Sonata Forms (1997), as its title stems exactly from the previously stated fact. 
Out of six analyzed sonata forms, it is noticeable that only one movement (Op. 18 No. 6 in B-flat Major) has a common recapitulation. All the sections of the exposition unfold according to the settled pattern and keep their form (the first and the second theme are in the form of a sentence, while the bridge and the closing section have a fragmentary structure). The tonal plan also follows a pattern common for the exposition and recapitulation (the bridge that modulates from B-flat Major to F-Major, the second theme and the closing section in the dominant key and recapitulation in the home key).

The minimum alterations in recapitulation are observable in the first movement of the string quartet Op. 18 No. 5 in A-Major, where alterations take place in the bridge manifested as widening of the section. Namely, the first theme (136-146) keeps its sentence form and ends on the tonic of the home key. The initial course of the bridge is preserved, but, differently from the exposition, it is of greater dimensions, with a significantly richer harmonic plan (use of altered diatonic chords $\left[\mathrm{F}, \mathrm{D}_{\mathrm{II}}\right]$, modulation to C-Major, a-minor and return to the home key, A-Major). Remarkable dynamization of recapitulation in the bridge is also reflected in the intensification of rhythm - by the use of the movement of eighth notes broken by rests of the same value, this achieving the effect of rhythmic acceleration. Additionally, intensified acoustic dynamics, i.e. $\mathrm{f}$ (forte) - $\mathrm{p}$ (piano) exchange, appears as a factor of dynamization.

Aside from the above mentioned, this movement also has an unusual tonal plan of B1 section in the exposition (25-43), as well as in the recapitulation (165-183). The expected key for the onset of the second theme (dominant E-Major) in the exposition is achieved during this section, namely in the last sentence of the double period $(4+4$, first period, $4+7$, second period). The first period has two sentences, the first ending on the dominant of eminor, and the second on the tonic of G-Major. The second period brings the first fourmeasure sentence in the part of the second violin, ending with the dominant on e-minor, while the second sentence is extended (7 measures), ending on the tonic of E-Major. The tonal instability of the section $\mathrm{B}_{1}$ is not rare, hence, the section $\mathrm{B}_{2}$ is often considered to be the 'real' second theme. The form of this section is preserved in the recapitulation, but the arrangement of the keys is altered (the first sentence is in a-minor, the second in C-Major, the third, by analogy with the first, again in a-minor, and the fourth in A-Major).

Ex. 1 Beethoven: String quartet Op. 18 No. 5

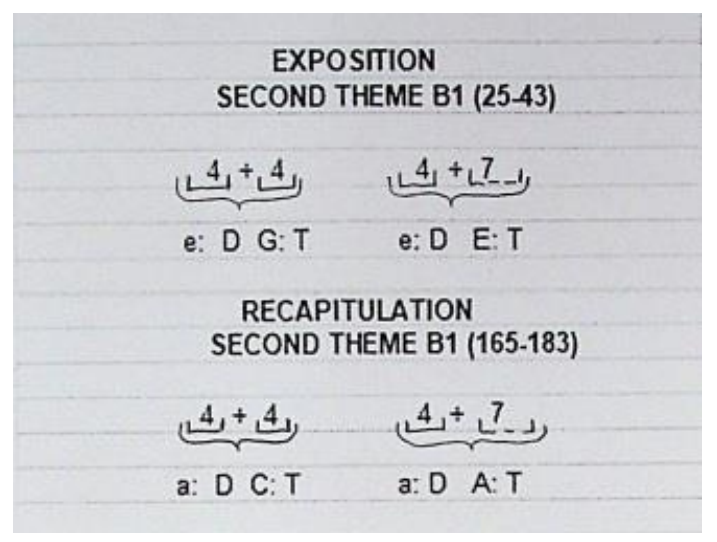


A slight extension of the recapitulation (in the transition) is also noticeable in the string quartet Op. 18 No. 2 in G-Major, but differently from the previous examples, a somewhat altered boundary between the first theme and the transition is noticeable too. The first theme in the exposition (1-20) is built as an eight-measure sentence (4+4), which is repeated with an internal extension $(4+4+4)$, and ends on the tonic of the home key. The onset of the bridge is divided by a caesura in the form of a rest, and it, ordinarily, modulates all the way to the dominant key. A clear division of the sections in the exposition (presence of an authentic cadence or half cadence, frequent use of a rest between the sections, etc.) is not present in the recapitulation. Namely, in the recapitulation there is a frequent alteration on the first theme bridge relation, which is partially understandable if one takes into account that the second theme "must" be preserved, i.e. rendered in the home key. That is exactly where recapitulation gets transformed in this sonata form; the second sentence of the first theme (instead on the tonic of the home key) modulates to a parallel minor (e-minor) and ends on the dominant (see Example 2). All the while, it is not based on a simple repetition of the content from the exposition, and it is modified in a way that can be referred to as dynamization (frequent repetition of a single-measure initial motif in the dialogue between the first and the second violin).

Another interesting thing is that the bridge (measure 170) continues the idea of the first theme both thematically and tonally - it continues to move in e-minor, but instead of its own motif from the exposition, it brings the content of the first theme (170-178), which in the further continuous course blends with the remaining content of the bridge (179-186) with a modulation to (the expected) G-Major.

Ex. 2 Beethoven: String quartet Op. 18 No. 2

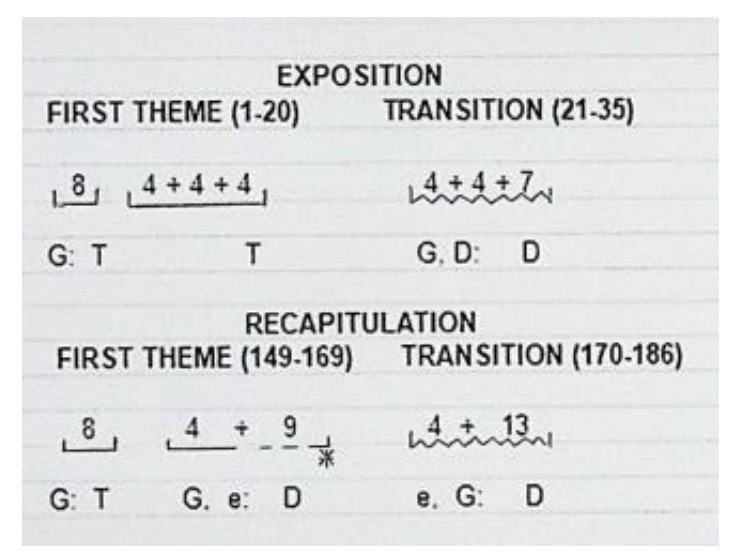

The idea of permeable boundaries (Popović 1998) between the adjacent sections in the recapitulation is not the exclusivity of this example. Namely, this procedure is proportionally often used in order to achieve greater integrity of the recapitulation, and to avoid monotony caused by mere repetition of the content of the exposition (Zdravić Mihailović 2006, 2007a, 2015a, 2015b).

What one can notice in the following three examples is the presence of the abbreviated recapitulation as a means of simple shortening of an individual section without the change 
of boundaries (Op. 18 No. 4), blending of adjacent sections (Op. 18 No. 3), or structural and tonal disruption (Op. 18 No. 1).

What is noticeable in the configuration of the music form of the first movement of the string quartet Op. 18 No. 4 in c-minor is a significant shortening of the bridge in the recapitulation. As for the exposition, the first theme (1-13) unfolds in the form of a sentence, followed by the bridge (14-33) of fragmentary structure, the second theme (34-70) with the sections B1 (in the form of a period 8+12) and B2 (a sentence of 17 measures), and the closing section (71-77). The peculiarity of this sonata form is in the treatment of the bridge in the exposition. Namely, the bridge consists of two subsections (12 and 8 measures), with the first bearing association to the external extension of the first theme with its chordal texture and exchange of tonic and dominant. However, a more detailed analysis reveals that such content still suits the bridge better due to the frequent movement on the dominant of the home key, as well as pedals and halts in the 25th measure. The key to the second theme actually prepares the second subsection of the bridge (26-33) which brings a relatively new thematic material and reaches the parallel between E-flat-Major through A-flat Major and f-minor.

In the recapitulation a broadly conceptualized bridge, with rich thematic and tonal plans, is reduced to the first part only (149-157), it remains in the home key (c-minor) and ends on the dominant, preparing the onset of the second theme. It is noticeable that this idea is in a way opposite to the idea of the enriching of recapitulation exactly on account of the alterations in the bridge: "the classicists readily use that particular moment to refresh recapitulation by some new harmonic twist or by a new thematic adaptation in order to avoid both the impression of cliched repetition of the material from the exposition and the harmonic monotony which might result from the prevalence of the home key" (Skovran i Peričic 1982, 157). A rather modest tonal plan is supplemented by the activity of acoustic dynamic, a chromatic movement of the melody in the highest voice, as well as by emphasizing rhythmic unison and chordal texture, thus making the bridge, i.e. recapitulation additionally atypical.

A greater degree of alteration of the bridge, i.e. of the first theme and of the bridge, can be seen in the sonata form of the first movement of the string quartet Op. 18 No. 3 in DMajor. Upon comparing the exposition and the recapitulation, it is noticeable that the highest degree of alterations is present in the relation between the first theme and the bridge. Namely, the first theme, which is represented by a sequence of sentences in the exposition (the first of 10, and the second of 17 measures), is reduced to 10 measures in the recapitulation, while the bridge, built as a 23-measure fragment in the exposition, gets reduced to 14 measures in the recapitulation. Aside from the reduction of the thematic material of the exposition in the recapitulation, i.e. the obvious shortening, another interesting point is the phenomenon of blending of these adjacent sections. The first theme has no cadence, that would clearly separate it from the beginning of the bridge; instead, the content which is actually common for the first theme and the bridge (the initial melody leap with longer note values and imitative texture followed by a gradual movement in eighth notes) builds on it after a deceptive closure (VIIVI-VI, measure 166-167). 
Ex. 3 Beethoven: String quartet Op. 18 No. 4

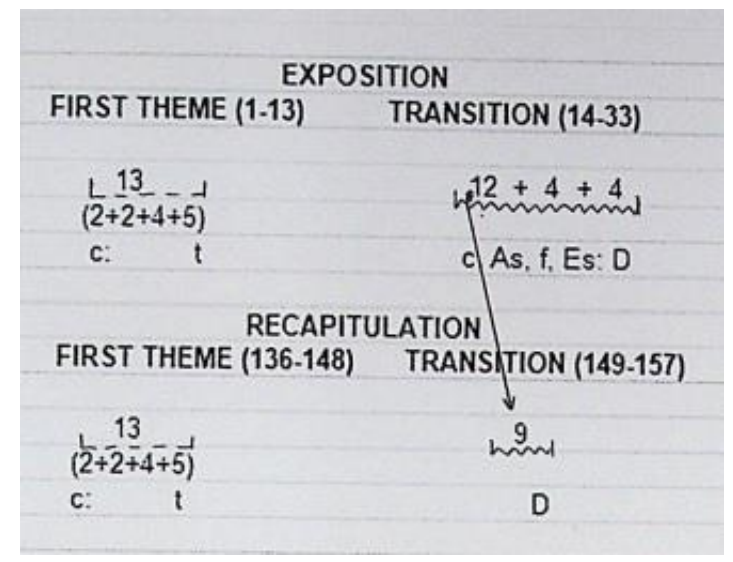

A peculiarity of recapitulation, besides the blending of the first theme and the bridge, lies in advancing to a subdominant key, G-Major (measure 168-174), which additionally enhances the content of the recapitulation. Thus, this unique section made up of the first theme and the bridge (10+14) substantially impairs the concept of recapitulation based on a simple repetition of the content of the exposition with a tonal alteration of the second theme and the closing section (optionally, of the bridge).

The first quartet from Op. 18 is distinguished by rich motif elaboration in the high classic style (Kinderman 2010, 14) and brings the most remote concept of the recapitulation by comparison with the exposition. Recapitulation exhibits alterations on both structural and tonal plans which significantly alter the content of the first theme and the bridge, while the second theme and the closing section remain completely preserved (similar to the other examples presented). The idea of "tonal reconciliation" of the first and the second theme in the recapitulation is thus called into question, but the basic idea of exposing the second theme in the home key is very consistently presented, too.

The first theme, which has the form of a period $(8+12)$ in the exposition with an external extension ( 9 measures), gets reduced in the recapitulation to the repetition of only the first sentence of the period, with a cadence on the dominant of the home key, F-Major. Hence, the firm periodic construction of the first theme in the recapitulation gets "decomposed" by preserving only the first sentence, while the second (which would "close" the periodic form) gets substituted by a fragmentary structure $(6+6)$ on the material of the external extension of the first theme (compare measures 21-22 with measures 187-188).

The first theme, which has the form of a period $(8+12)$ in the exposition with an external extension ( 9 measures), gets reduced in the recapitulation to the repetition of only the first sentence of the period, with a cadence on the dominant of the home key, F-Major. Hence, the firm periodic construction of the first theme in the recapitulation gets "decomposed" by preserving only the first sentence, while the second (which would "close" the periodic form) gets substituted by a fragmentary structure $(6+6)$ on the material of the external extension of the first theme (compare measures 21-22 with measures 187-188). Progressive tendencies in the recapitulation are also manifested through the significant alterations of the tonal plan. Namely, recapitulation only begins in the home key, F-Major, but then it takes the course 
through D-flat Major and G-flat-Major, and closes on the tonic (measure 198). In its further course through the bridge (199-217), it unfolds on the tonal basis of G-flat Major and f-minor, and finally makes it to the home key. By this procedure, the composer makes an unusual blend of the first theme and the bridge which gives itself to a twofold interpretation. According to the features of the thematic plan, it can be said that the first theme ends in the 198th measure, because what is exposed from the 199th measure on is the material of the bridge of the exposition. However, bearing in mind the tonal and structural plans (leaving the home key and modulation to D-flat Major and G-flat Major, as well as a fragmentary character of the structure) it can be concluded that this segment bears the characteristics of the central type of exposure and, accordingly, does not correspond to the first theme, rather it belongs to the bridge. According to this interpretation, the first theme would be only the 8-measure sentence (179-186), while the bridge would have two sub-sections (187-198 and 199-217).

Ex. 4 Beethoven: String quartet Op. 18 No. 1

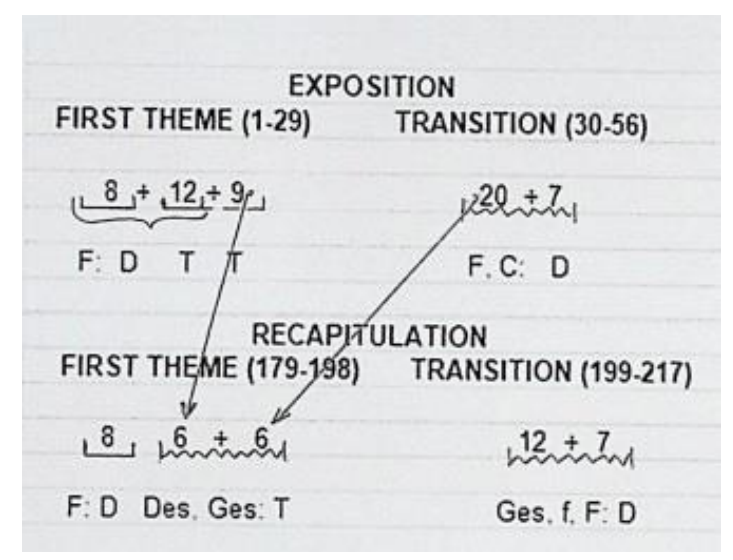

According to its features, the described recapitulation is reminiscent of the so-called premature recapitulation (compare Sabo 1994, 87; Zdravić Mihailović 2015a, 105). Such a recapitulation implies that the first theme starts before "the conditions have been met" in the musical course for its onset. It is not characterized by an exposition-type presentation which is typical for the first theme. Instead, here the author still operates with the material, which is a typical for the development. In the sphere of harmonic-tonal way of thinking, it means that the first theme does not occur in the home key. The home key is established later, during the first theme, within the bridge or not before the second theme. Still, this is not a representative example of a premature recapitulation, but of a specific blend of alterations on the structural and tonal plans. The initial segment of the recapitulation brings about a recognizable content of the first theme, and at that point it is not possible to portend a greater degree of dynamization of the musical course. This procedure can be seen in the bridge (measure 199208) where the motif borrowed from the first theme and involving dotted rhythm (a dotted quarter note, two sixteenth notes and two eighth notes) takes turns with the motif of the bridge which contains a trill and dotted rhythm, too (a dotted quarter note and three eighth notes). While in the exposition these motifs appeared simultaneously in the parts of the first violin and the cello, in the recapitulation they appear alternately in the parts of the first violin and the 
viola. Thus the musical course acquires agility, dynamism which was not typical for the exposition and the sonata form as a whole acquires completely specific traits.

Ex. 5 Beethoven: String quartet Op. 18 No. 1
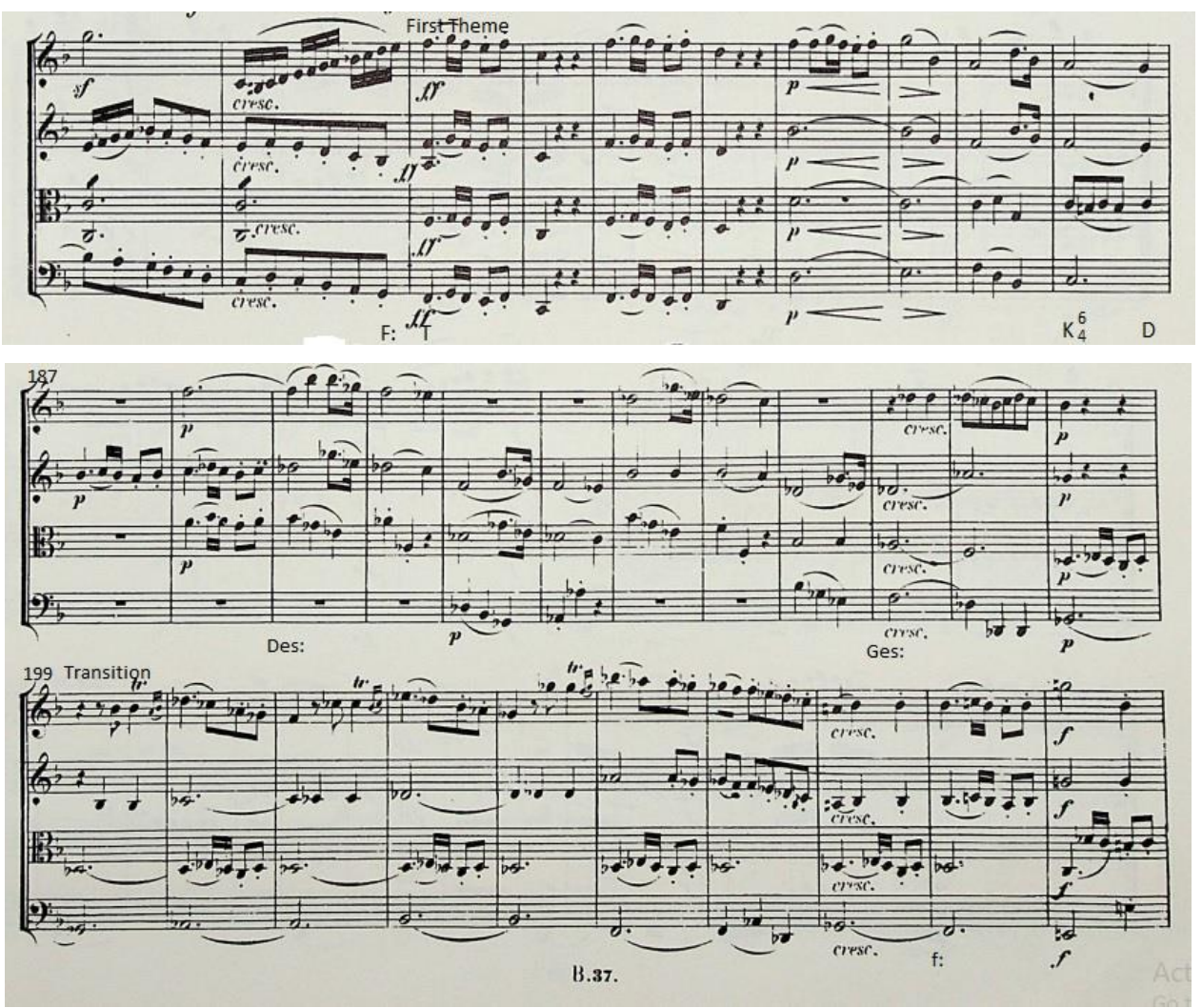

\section{CONCLUSION}

Upon considering the treatment of recapitulation in the first movements of Beethoven's string quartets Op. 18, it can be asserted that they do not exemplify significant deviations from the common concept, primarily in terms of the order of presenting the sections. However, when it comes to the treatment of individual sections, it is possible to notice some minor, common, but rather significant alterations.

This paper focuses on the analysis of a chosen opus using the criterion of the degree of remoteness from the common presentation of the recapitulation. Thus, it is possible to assert that in the string quartets Op. 18 No. 6 there are some expected alterations of the bridge (minor interventions on the thematic plan, along with a common tonal alteration), while in the quartet Op. 18 No. 5, it is noticeable that there is a discrete extension of the bridge in the recapitulation, as well as a richer tonal plan.

A particularly sensitive field, which is reserved for the first theme - bridge relation, sometimes also reveals the deviations on the tonal plan as early as in the first theme (Op. 
18 No. 2).It is possible to notice here the presence of a developmental principle within the first theme, i.e. in its second sentence (measure 157-169); its divisibility into three segments from the exposition $(4+4+4)$ is reduced to two (4+9) which, along with the modification of the content of the bridge (rhythmical acceleration caused by using smaller note values, in this particular case the use of small triplets instead of sixteenth notes), affects the entire dynamization of the musical course.

All in all, this research confirms the results of previous findings based on the assertion that the procedure of shortening or compression is more frequent than extension in the recapitulation (compare Zdravić Mihailović 2015a, p. 113). The movements from the Op. 18 No. 3, Op. 18 No. 4 and Op. 18 No. 1) have a partially shorter recapitulation. For example, in the first movement of the string quartet Op. 18 No. 4 it is noticeable that the bridge is twice shorter than the same section in the exposition, and that it is reduced to its basic function, i.e. to connect the two themes.

A greater degree of alterations, coupled with blending of the adjacent sections (the first theme and the bridge) is presented in the quartet Op. 18 No. 3. The procedure of shortening, i.e. compression of the exposition found its place here, thanks to the reduction of the content of the bridge, as well as in the use of a deceptive closure on the VI degree (measure 167).

Recapitulation which is the most remote by comparison to the exposition is to be found in the first quartet of the mentioned opus. It is there that shortening and compression of the musical course become evident. Coupled with the tonal alterations, they affect recapitulation in such a way as to give it a new role - instead of simple repetition of the exposition with the usual alterations, it becomes a spot of a new development on several musical plans. This proves that recapitulation, aside from its basic role to resolve the exposition, can be a point of development itself (compare Мазель 1979, 408).

Besides the major points of analytical observations (thematic, tonal and structural plans), as well as the analysis of the dominant musical components - melody, rhythm, harmony - the alterations in the organization of texture, melodic lines or acoustic dynamics (e.g. the synergy of the melodic chromatic movement upwards followed by an increase of acoustic dynamics and alteration of articulation (the bridge in the recapitulation of the Op. 18 No. 4) or acoustic dynamics and rhythmic acceleration also play an important role in the dynamization of the musical course of recapitulation.

Various adaptations of recapitulation and intensification of the activity of musical components primarily occur in order to avoid mechanical repetition and the monotony that mere repetition would cause. This very fact hides a whole array of creative approaches that have been only partially elucidated by this research.

Acknowledgement: The paper is the part of the project of the SASA (Serbian Academy of Sciences and Arts) Branch in Niš "The Music Heritage of Southeast Serbia, Contemporary Creativity and taste education", O-10-17.

\section{REFERENCES}

Cook, N., (1987), A Guide to Musical Analysis, J.M. Dent \& Sons Ltd, London \& Melbourne.

Kinderman, W., (2006), The String Quartets of Beethoven, University of Illinois Press.

Мазель, Л. А., (1979), Строение музикаыньх произведений, Музыка, Москва.

Mihajlović, M., (1989), Muzički oblici [Musical Forms], Institute for Textbook Publishing and Teaching Aids Belgrade, Publishing Company "Nota" - Knjaževac, Institute for Textbook Publishing - Novi Sad. 
Popović, B., (1998), Muzička forma ili smisao u muzici [Musical Form or Purport in Music], Belgrade, Clio.

Rozen, Č., (1979), Klasični stil - Hajdn, Mocart, Betoven [Classical Style - Haydn, Mozart, Beethoven], Nolit, Belgrade.

Rosen, C. (1997)., Sonata Forms, W. W. Norton \& Company, New York - London.

Sabo, A., (1994), "Aleksandar Obradović: Koncert za violinu i gudačke instrumente i muzika za klavir i gudače" [ Aleksandar Obradović: Concert for Violin and String Instruments and Music for the Piano and Strings], Novi zvuk no. 3, Serbian Music Authors' Organization, Belgrade, p. 85-96.

Skovran, D. and V. Peričić, (1982), Nauka o muzičkim oblicima [The Study of Musical Forms], University of Arts, Belgrade.

Stamatović, I., (2004), "Sonatni oblik i sonatni princip" [Sonata Form and Sonata Principle] In Muzička teorija i analiza 1 [Musical Theory and Analysis I], Journal of the Department for Musical Theory, Mirjana Živković, Ana Stefanović, Miloš Zatkalik (Ed.), Faculty of Music, Belgrade, pp. 101-109.

Zatkalik, M., Medić M. and Vlajić, S., (2003), Muzička analiza I [Musical Analysis I], Clio, Belgrade.

Zdravić Mihailović, D., (2006), "Vidovi dinamizacije reprize u sonatnom obliku klasičara" [Forms of Dynamization in the Classicists' Sonata Form], Journal for Literature, Language, Art and Culture Nasleđe no. 4: pp. 131-137.

Zdravić Mihailović, D., (2007a), "Specifičnost dramaturgije sonatnog oblika kao odraz dinamizacije reprize u prvom stavu simfonijskog ciklusa - Franz Jozef Hajdn: Londonske simfonije" [Pecularities of Dramaturgy of the Sonata Form as a Reflection of Dynamization of Recapitulation in the First Movement of the Symphonic Cycle - Franz Josef Haydn: London Symphonies], In: Dimitrije O. Golemović (ed.), International scientific meeting Tradicija каo inspiracija. Vlado S. Milošević kompozitor, etnomuzikolog i pedagog [Tradition as an Inspiration. Vlado S. Milošević Composer, Ethnomusicologist and Pedagogist], Proceedings. Art Academy, Musicological Society of the Republic of Srpska, Banja Luka, pp. 217-225.

Zdravić Mihailović, D., (2007b): "Status reprize u sonatnom obliku", [Status of Recapitulation in Sonata Form] In: Muzička teorija i analiza 4: Zbornik Katedre za muzičku teoriju [Musical Theory and Analysis 4: Journal of the Department for Musical Theory], Mirjana Živković, Ana Stefanović, Miloš Zatkalik, Ivana Stamatović i Slobodan Raicki (ur.), Fakultet muzičke umetnosti, Beograd, pp. 59-73.

Zdravić Mihailović, D., (2015a), Fenomen reprize u sonatnom obliku - prvi stavovi gudačkih kvarteta Franca Jozefa Hajdna [Phenomenon of Recapitulation in the Sonata Form - First Movements of Franz Josef Haydn's String Quartets], Faculty of Arts of the University of Niš and Joint Research Center of the Serbian Academy of Arts and Sciences and the University of Niš.

Zdravić Mihailović, D., (2015b), "Osobenosati kompoziciono-tehničkih rešenja reprize u sonatnom obliku klasičara" [Pecularities of Compositional-Technical Solutions of Recapitulation in the Classicists' Sonata Form] In: International scientific meeting Tradicija кao inspiracija. Vlado S. Milošević kompozitor, etnomuzikolog i pedagog, [Tradition as an Inspiration. Vlado S. Milošević Composer, Ethnomusicologist and Pedagogist], Proceedings. Dr Sonja Marinković, Dr Sanda Dodik (ed.), Art Academy, Banja Luka, pp. 421-436.

Zdravić Mihailović, D., (2016), "Classical Sonata Form in Serbian Music Textbooks", Facta Universitatis Visual Arts and Music, Vol. 2, No. 1, pp. 31-36.

\section{TRETMAN REPRIZE U PRVIM STAVOVIMA SONATNOG OBLIKA BETOVENOVIH GUDAČKIH KVARTETA OP. 18}

U radu se razmatra funkcija reprize u sonatnom obliku, na primeru prvih stavova Betovenovih gudačkih kvarteta op. 18 br. 1-6. S obzirom na činjenicu da se repriza najčešće opisuje kao ponavljanje ekspozicije uz tonalnu izmenu druge teme i završne grupe, analitička razmatranja najčešće se svode na evidentiranje tih izmena. Međutim, ponekad se ukazuje i na novu ulogu reprize upravo zbog smisla sprovedenih izmena, tj. zbog ideje koju kompozitor želi da ostvari na nivou sonatnog oblika putem reprize. Istraživanje je zamišljeno kao nastavak ranijih istraživanja (Zdravić Mihailović 2006, 2007a, 2007b, 2015a, 2015b), koji su u fokus stavljali žanr gudačkog kvarteta Hajdna (Franz Joseph Haydn) $i$ Mocarta (Wolfgang Amadeus Mozart), gde se pokazalo da je repriza svojevrsan fenomen, $i$ da njena uloga nije samo prezentovanje sadržaja ekspozicije uz uobičajene tonalne izmene. Naprotiv, ona može da predstavlja i mesto novog tretmana odseka iz ekspozicije, pri čemu dobija i sasvim specifična obeležja.

Ključne reči: repriza, sonatni oblik, Betoven, gudački kvartet. 